\title{
Controlling Shareholders and Managers' Discretionary Expenditures
}

\author{
Jaisik Gong ${ }^{1}$ \\ ${ }^{1}$ Professor, Dept. Finance \& Insurance, Daegu University, Korea, bkgong@daegu.ac.kr
}

\begin{abstract}
This paper aims to examine the causal relationship between the controlling shareholders and the discretionary expenditures of managers in Korean firms. The prevailing western literature supported the expropriation effect hypothesis regarding the role of controlling shareholders in firms. The expropriation effect hypothesis argues that the controlling shareholders are likely to change the firm's operational activities for their perks, expropriating the interests of the minority shareholders. However, the incentive effect hypothesis argues that controlling shareholders pursue a long-term investment and a good family reputation to be passed onto their succeeding generations. They are less likely to take firm value-decreasing and family reputation-impairing decisions. This study made a scientific analysis as to whether Korean companies engaged in the entrenchment management of the controlling shareholders or the exploitation activities of minority shareholders' property, or as to whether the controlling shareholders were alleviating the agency problems by implementing a business strategy for increasing corporate value. This means that the controlling shareholders in Korean firms decrease agency costs of managers and seek firm value-increasing management. This paper found that the controlling shareholders in Korean firms were negatively associated with managers' discretionary expenditures. This finding suggests that controlling shareholders think of their companies as important assets to manage while preserving their family's reputation, thus supporting the incentive effect hypothesis.
\end{abstract}

Keywords: Controlling Shareholders, Discretionary Expenditures, Real Earnings Management, Agency Problem, Corporate Governance

\section{Introduction}

Berle and Means[1] first mentioned that modern companies were characterized by the separation of ownership and management and the extensively dispersed ownership structure. Since then, many studies have been conducted on the conflicts and problems between shareholders and managers or between controlling shareholders and minority shareholders in corporations.

The agency problems that could arise between shareholders and managers, or between controlling and minority shareholders, have been highlighted in the transition process from private companies to corporations. In particular, as Claessens, Djankov, Fan and Lang[2][3] noted, many companies in East Asian countries have family-centered controlling shareholders who are directly managing the company, acting as directors on the board of directors of the company, or are dominating the company by nominating the CEO of the company. However, in the case of family-centered controlling shareholders in many companies in East Asian countries, the agency problem between the controlling shareholders and minority shareholders may appear more serious.

Achleitner, Gunther, Kaserer and Siciliano[4] have found that German family companies with

Received: August 09, 2020; $1^{\text {st }}$ Review Result: September 24; $2^{\text {nd }}$ Review Result: November 04, 2020 Accepted: December 28, 2020 
controlling majority shareholders sought to increase their long-term corporate value and managed discretionary expenses such as $R \& D$ expenditures, advertising expenditures, education and training expenditures, and travel expenditures to maintain their dominance over their own businesses as well as their sustainability in the future. Their study showed that the German family companies were conducting real earnings management to curb discretionary expenditures of managers. Stein[5] argued that the controlling shareholders of a family company seek for long-term development of the said company, which may be the only large investment asset of their family, and to protect their family reputation. He added that those controlling shareholders avoid shortsighted and myotic management decisions that lead to corporate value reduction. The dominant shareholders of a family enterprise are expected to suppress the discretionary expenditures of the manager because of the incentive effect of the long-term development of their business, the increase of corporate value, and the need to maintain their family reputation. Razzaque, Ali and Mather[6] reported that the real earnings management activities, such as managing CEO's discretionary expenditures, were large at the low stage of controlling shareholder's stake in the family company where he works. They also found that the higher the controlling shareholder's stake, the lower the discretionary expenditure incurred by the manager, and the more the inducement effect there will be.

On the other hand, Jensen and Meckling[7] argued that the controlling shareholders had an incentive to exploit the property of minority shareholders, even if they manipulated the firm's accounting profits. Lemmon and Lins[8] argued on the entrenchment and exploitation effects of the controlling shareholders when the dominating shareholders controlled the corporate assets substantially to pursue their own private interests and thus exploiting the property of the minority shareholders. The controlling shareholders have entrenchment and exploitation incentives to increase their private consumption expenditures and to increase their personal property growth while causing losses to the property of minority shareholders without any cost payment or liability.

Gopalan and Jayaraman[9] argued that the greater the voting control compared to the cash flow rights, the greater use of the private interest-seeking motivation-driven accrual-based earnings managements followed. Ge and Kim[10] and Jaisik Gong[11] reported that corporate managers often attempted to exaggerate the accounting reporting profits for the current year in order to obtain the target credit rating for their smooth capital procurement, while managers reduced discretionary expenditures such as advertising expenses, employee training expenses, and maintenance expenses. Attig, Chen, Ghoul, Guedhami, Kwok and Pittman[12] and Jaisik Gong[13] analyzed the corporate ownership structure of East Asian countries, and they found that real earnings management was widely occurring in family-dominated companies, and that the wider the earnings management was seen when the investor protection device was weak, the demand for borrowing funds was high. Osma[14] and Kim Namgon[15] argued that managers often cut corporate R\&D costs at their discretion to pursue the firm's short-term profits. He claimed that if the board of directors worked well in companies, the board of directors could block the discretionary R\&D cost-cutting behavior of managers that might cause corporate value reduction. Cohen, Mashruwala and Zach[16] and Jee-Hyun Kim and Nam-Gon Kim [17] reported that corporate managers decided on corporate advertising spending cuts to achieve their corporate profit goals or avoid losses.

This study proposes the contribution of the incentive effect of the controlling shareholders among Korean companies to the improvement of corporate value by easing the agency costs between shareholders and managers. However, an opposite argument to this statement is raised as a tunneling effect where the controlling shareholders may exploit the property of minority shareholders through the tunnel, which may exacerbate the agency problems through the entrenchment effect. The verification of the incentive effect of controlling shareholders and the exploitation or tunneling effect of the properties of the minority shareholders were revealed through various statistical analyses. We aim to examine how the discretionary expenditure of the manager is affected by the change in the 
corporate ownership stake

This study analyzes the changes in the cost expenditures such as R\&D cost, advertising propaganda cost, employee training cost, and travel expenses that the management, directed by controlling shareholders, can adjust discretionarily in Korean companies. Through this, we will verify the inducement effect of corporate value by the controlling shareholders, the exploitation effect on the minority shareholders, and its tunneling effect.

\section{Methodology}

The subjects of the study are sample Korean companies traded in the Korean capital market from 2002 to 2017. Their 18-year time-series cross-sectional financial statements are analyzed using statistical research models.

This study examined the incentive effect, the entrenchment effect, and the exploitation effect of controlling shareholders through the causal relationship analysis between the presence of the controlling shareholders and the discretionary expenditure of the managers. A controlling shareholder is an individual or a family member holding at least more than 20 percent of the total stock shares of the company. This is consistent with the Korea Accepting-International Accounting Reporting Standards (K-IFRS) code that stipulates a significant stake in the company with holding ownership of more than $20 \%$. The dominant shareholders of the companies used in this study can also be classified as family enterprises. Faccio and Lang[18] defined a family enterprise's share ratio as $20 \%$. The main independent variable in this study model is the dummy variable designating whether the controlling shareholder exists or not. If the controlling shareholder has an ownership stake of more than $20 \%$, the controlling shareholder dummy variable $(\mathrm{CB})$ is given the number 1, and in other cases, the controlling shareholder dummy variable $(\mathrm{CB})$ is given the number zero.

The dependent variable of this research model is the real earnings management which represents the degree of the management's discretionary adjustment of the actual business activities to exaggerate the financial statement reporting profits. It is a variable (DisExp) measured as the sum of the discretionary expenses of the management including $\mathrm{R} \& \mathrm{D}$ cost, advertising propaganda cost, and employee training cost. In this study, the control variables are extra cash flow (FCash), total sales (Sales), leverage ratio (Lev), total asset (Size), asset return (ROA), and dividend ratio (DivRatio). This study examines the influence of the presence of the dominant shareholders, that is, it investigates the impact of the dummy variable (CB) on the discretionary expenditure (DisExp) of the manager, considering above control variables.

This study conducts statistical verification using the analysis model below.

$\frac{\text { DisExpi, } t}{\text { Salesi, } t}=\alpha 0, i+\alpha 1, i F C a s h i, t+\alpha 2, i$ Salesi, $t+\alpha 3, i \operatorname{Lev} i, t+\alpha 4, i \mathrm{CB} i, t+\alpha 5, i \operatorname{Size} i, t+\alpha 6, i \mathrm{ROA} i, t+\alpha 7, i$ DivRatio $i, t+\epsilon \mathrm{i}, \mathrm{t}$

This study shows that if the dummy variable (CB) for the controlling shareholders has a significantly negative estimate on the discretionary expenditure (DisExp/Sales) for the manager, the incentive effect of the controlling shareholders is confirmed. On the contrary, if a significantly positive estimate is shown, the exploitation and tunneling effect of the minority shareholder's property is confirmed.

The null hypothesis for verification in this study is set as follows.

$\mathrm{H}$ : The dominant shareholder dummy variable (CB) has no significant correlation with the discretionary expenditure proxy variable (DisExp/Sales). 


\section{Research Results}

[Table 1] presents the sample descriptive statistics for the main variables of this study including their average and standard deviation.

The DisExp, a variable of discretionary expenditure of managers, calculates the ratio of the total amount of $\mathrm{R} \& \mathrm{D}$ expenditure, advertising expenditure, employee training expenditure, and travel expenditure to the total sales. The average of DisExp, a discretionary expenditure variable, is 0.1845 and its standard deviation is 0.191 . The independent variable CB is a dummy variable that represents the ownership stake of the controlling shareholder. If the ownership stake of the controlling shareholder is more than $20 \%, \mathrm{CB}$ is equal to 1 . If the ownership stake of the controlling shareholder is less than $20 \%, \mathrm{CB}$ is equal to 0 .

The average of the controlling shareholder's stake dummy variable CB is 0.53 , and its standard deviation is 0.49 . The control variables include free cash flow (FCash), total sales (Sales), leverage ratio (Lev), total assets (Size), total asset return (ROA), dividend payment ratio (DivRatio), market value to book value (MKBK), and beta coefficient (Beta). The averages and the standard deviations for these control variables are also presented in [Table 1].

[Table 1] Sample Descriptive Statistics

\begin{tabular}{|c|c|c|c|c|c|}
\hline Variable & $\mathrm{N}$ & Average & Standard Deviation & Minimum Value & Maximum Value \\
\hline \hline DisExp & 7,485 & 0.1845 & 0.191 & 0 & 2.412 \\
\hline FCash & 4,534 & 30.450 & 1.862 & 20.469 & 37.372 \\
\hline Sales & 7,485 & 26.279 & 1.624 & 20.290 & 32.718 \\
\hline Lev & 7,502 & 1.191 & 2.497 & 0 & 88.879 \\
\hline CB & 7,502 & 0.53 & 0.49 & 0 & 1.0 \\
\hline Size & 7,489 & 26.540 & 1.459 & 22.611 & 32.794 \\
\hline ROA & 7,489 & 0.00026 & 0.0012 & -0.034 & 0.0336 \\
\hline DivRatio & 7,502 & 0.016 & 0.103 & 0 & 0.494 \\
\hline MKBK & 7,058 & 17.949 & 58.245 & 0.150 & 1740.0 \\
\hline Beta & 7,502 & 0.725 & 0.457 & 0 & 18.970 \\
\hline
\end{tabular}

*Note: DisExp is managers'discretionary expenditures. FCash is free cash flows, and Sales is total sales amount. Lev is the ratio of financial leverage. $\mathrm{CB}$ is a dummy variable in which $\mathrm{CB}=1$ if controlling shareholders hold more than $20 \%$ of the firm's total equity and $\mathrm{CB}=0$ if otherwise. Size is the logarithm of total assets, a corporate size variable. ROA is the ratio of total asset returns, and DivRatio is a dividend payment ratio. MKBK is the ratio of the common stock market to book value. Beta is a beta coefficient index, a risk measure.

[Table 2] and [Table 3] are the results analyzing the impact of the presence of a controlling shareholder on the discretionary cost expenditure of the manager. If the larger the stake of the controlling shareholder, the higher the discretionary expenditure of the manager. The positive correlation between the ownership stake of the controlling shareholder and the discretionary expenditure of the manager suggests the tunneling effect where the controlling shareholder directly affects the manager, thereby enforcing the manager to increase the discretionary expenditure of the company by adjusting the actual business activities. Consequently, this exploits the minority shareholders because their properties move to the controlling shareholders'firms.

Conversely, If the larger the stake of the controlling shareholder, the less discretionary cost 
expenditure of the manager. The negative correlation between the stake of the controlling shareholder and the discretionary cost expenditure of the manager suggests that the controlling shareholder has a great incentive to pursue firm value management, which is the top priority for the firm's long-term survival, growth and family reputation. The controlling shareholders'family company is the start-up assets which family members have built so far. Thus, they want to reduce the discretionary expenditure of the company to control the agency costs as much as possible.

In Model 1 of [Table 2], the coefficient estimate of the dummy variable (CB) indicating the controlling shareholder's share stake on the discretionary expenditure (DisExp) of the manager is 0.0179 , its $\mathrm{t}$-Val is -3.29 , and its $\mathrm{p}$-value is 0.0010 . The coefficient estimates of the control variables such as the free cash flow (FCash) and the enterprise size variable (Size) are 0.0087 and 0.052 , respectively. Their t-Vals are 3.85 and 12.94 , and their $p$-values are quite smaller than 0.0001 . The coefficient estimates of sales growth rate (Sales) and leverage ratio (Lev) are -0.0706 and -0.0048 , and their $\mathrm{t}$-Vals are -22.5 and -4.20 . Their p-values are also quite smaller than 0.0001 .

In Model 2 of [Table 2], the coefficient estimate of the dominant shareholder dummy variable (CB) is -0.0170 , its $\mathrm{t}-\mathrm{Val}$ is -3.15 , and its $\mathrm{p}$-value is 0.0016 . The coefficient estimate for the discretionary expenditures of the managers (DisExp) is 0.086 . As for control variables, the coefficient estimates for free cash flow (FCash), corporate size variable (Size) and dividend payment ratio (DivRatio) are $0.086,0.048$, and 0.0117 , respectively. Their t-Vals are 3.87, 11.96, and 8.75, respectively. The coefficient estimate of sales growth (Sale) is -0.0729 , the coefficient estimate of leverage ratio (Lev) is -0.0043 , and all of them have negative t-Vals, which are statistically significant at the $1 \%$ level of significance.

[Table 2] Effects of Controlling Shareholders on Managers'Discretionary Expenditures

- Dependent Variable: DisExp (Managers'Discretionary Expenditures)

\begin{tabular}{|c|c|c|c|c|c|c|}
\hline \multirow{2}{*}{ Variable } & \multicolumn{5}{|c|}{ Model 1 } & \multicolumn{3}{c|}{ Model 2} \\
\cline { 2 - 7 } & Coeff Est & t-Val & Pr> ItI & Coeff Est & t-Val & Pr $>$ ItI \\
\hline \hline Intercept & 0.408 & $7.93^{* *}$ & $<.0001$ & 0.572 & $10.53^{* *}$ & $<.0001$ \\
\hline FCash & 0.0087 & $3.85^{* *}$ & 0.0001 & 0.0086 & $3.87^{* *}$ & 0.0001 \\
\hline Sales & -0.0706 & $-22.5^{* *}$ & $<.0001$ & -0.0729 & $-23.3^{* *}$ & $<.0001$ \\
\hline Lev & -0.0048 & $-4.20^{* *}$ & $<.0001$ & -0.0043 & $-3.78^{* *}$ & 0.0002 \\
\hline CB & -0.0179 & $-3.29^{* *}$ & 0.0010 & -0.0170 & $-3.15^{* *}$ & 0.0016 \\
\hline Size & 0.052 & 12.94 & $<.0001$ & 0.048 & $11.96^{* *}$ & $<.0001$ \\
\hline ROA & 4.659 & 2.24 & 0.0254 & 4.606 & $2.23^{* *}$ & 0.0258 \\
\hline DivRatio & & & & 0.0117 & 8.75 & $<.0001$ \\
\hline
\end{tabular}

*Note: DisExp is managers'discretionary expenditures. FCash is free cash flows, and Sales is total sales amount. Lev is the ratio of financial leverage. $\mathrm{CB}$ is a dummy variable in which $\mathrm{CB}=1$ if controlling shareholders hold more than $20 \%$ of the firm's total equity and $\mathrm{CB}=0$ if otherwise. Size is the logarithm of total assets, a corporate size variable. ROA is the ratio of total asset returns, and DivRatio is a dividend payment ratio.

In [Table 3], the effect of the ownership ratio of the controlling shareholder on the discretionary expenditure of the management was analyzed, including the market value to book value ratio variable (MKBK) and beta coefficient variable (Beta) in addition to Model 1 and Model 2. In Model 3 of 
[Table 3], the coefficient estimate of the dummy variable (CB) for the controlling shareholder is 0.0143 , its t-Val is -2.68 , and p-value is 0.0074 . In Model 4 of [Table 3], the coefficient estimate of dummy variable $(\mathrm{CB})$ for the controlling shareholder share is -0.0147 , its $\mathrm{t}$-Val is 2.77 , and p-value is 0.0056. The estimation results for the control variables in Model 3 and Model 4 of [Table 3] are almost identical to the estimation results for the control variables in Model 1 and Model 2 of [Table 2].

[Table 3] Effects of Controlling Shareholders on Managers'Discretionary Expenditures

- Dependent Variable: DisExp (Managers'Discretionary Expenditures)

\begin{tabular}{|c|c|c|c|c|c|c|}
\hline \multirow{2}{*}{ Variable } & \multicolumn{3}{|c|}{ Model 3} & \multicolumn{3}{|c|}{ Model 4} \\
\hline & Coeff Est & $\mathrm{t}-\mathrm{Val}$ & $\operatorname{Pr}>$ ItI & Coeff Est & $\mathrm{t}-\mathrm{Val}$ & $\mathrm{Pr}>\mathrm{ItI}$ \\
\hline Intercept & 0.642 & $11.90^{* *}$ & $<.0001$ & 0.614 & 11.28 & $<.0001$ \\
\hline FCash & 0.0070 & $3.17^{* *}$ & 0.0015 & 0.0071 & $3.22 * *$ & 0.0013 \\
\hline Sales & -0.0721 & $-23.42^{* *}$ & $<.0001$ & -0.0715 & -23.22 & $<.0001$ \\
\hline Lev & -0.0036 & $-3.22 * *$ & 0.0013 & -0.0034 & $-3.03^{* *}$ & 0.0025 \\
\hline $\mathrm{CB}$ & -0.0143 & $-2.68 * *$ & 0.0074 & -0.0147 & $-2.77 * *$ & 0.0056 \\
\hline Size & 0.0461 & $11.63^{* *}$ & $<.0001$ & 0.0469 & 11.85 & $<.0001$ \\
\hline ROA & 1.879 & 0.92 & 0.359 & 1.600 & 0.78 & 0.435 \\
\hline DivRatio & 0.00824 & 6.03 & $<.0001$ & 0.00821 & 6.01 & $<.0001$ \\
\hline MKBK & 0.00044 & 10.96 & $<.0001$ & 0.00044 & $10.93 * *$ & $<.0001$ \\
\hline Beta & & & & -0.019 & -3.47 & 0.0005 \\
\hline
\end{tabular}

*Note: DisExp is managers'discretionary expenditures. FCash is free cash flows, and Sales is total sales amount. Lev is the ratio of financial leverage. $\mathrm{CB}$ is a dummy variable in which $\mathrm{CB}=1$ if controlling shareholders hold more than $20 \%$ of the firm's total equity and $\mathrm{CB}=0$ if otherwise. Size is the logarithm of total assets, a corporate size variable. ROA is the ratio of total asset returns, and DivRatio is a dividend payment ratio. MKBK is the ratio of the common stock market to book value. Beta is a beta coefficient index, a risk measure.

The analyses of the models 1, 2, 3, and 4 in both [Table 2] and [Table 3] show very robust estimates. The most prominent analysis result is that the dummy variable (CB) for the controlling shareholder's stakes shows a very significant negative correlation with the discretionary expenditure of the manager (DisExp), suggesting that the larger the controlling shareholder's stakes, the lower the manager's discretionary cost expenditure. This means that the agency cost is controlled. This also suggests that the larger the majority shareholder share, the more likely the majority shareholders are to take the company as a permanent asset of the family to hand over to their future generations, rather than to take advantage of the minority shareholders' property through the tunnel. The estimated results of [Table 2] and [Table 3] do not support the entrenchment and tunneling effects of the dominant shareholders in Korean firms, but provide statistical evidence that is strongly consistent with the incentive effect hypothesis emphasizing the reputation of family companies.

The analyses of control variables show that the more the free cash flow, the larger the corporation, the better the future growth potential, and the greater the agency cost, the larger the discretionary expenditures of the manager are occurring. In addition, the results provide that the higher the sales growth rate, the higher the debt level, and the higher the corporate risk, the lower the discretionary 
expenditure level of the management are incurring.

\section{Robustness Tests}

In this chapter, we conducted a robustness analysis on whether the empirical results of the effect of the controlling shareholders on the discretionary expenditures of the managers analyzed in the previous chapter can be different depending on the sub-samples divided from the entire sample period. If the results of the empirical analysis vary according to the sample size used, the results obtained from the analysis in the previous chapter cannot be said to be robust because the analysis results can be distorted.

Since the International Financial Reporting Standard (IFRS), which is an internationally used accounting standard, has been mandatory for Korean listed companies since 2011, it is expected that domestic companies will have significantly different earnings management behaviors and business activities around 2011. Therefore, the sample period of this study was divided into the period of 20042010, which is the period before the enforcement of Korea-adopting-International Financial Reporting Standard (K-IFRS), and the period of 2011-2017, which is the period after the introduction of K-IFRS.

[Table 4] Effects of Controlling Shareholders on Managers'Discretionary Expenditures

- Dependent Variable: DisExp (Managers'Discretionary Expenditures)

- Pre K-IFRS (2004-2010) -

\begin{tabular}{|c|c|c|c|c|c|c|}
\hline \multirow{2}{*}{ Variable } & \multicolumn{3}{|c|}{ Model 1} & \multicolumn{3}{|c|}{ Model 2} \\
\hline & Coeff Est & $\mathrm{t}-\mathrm{Val}$ & $\mathrm{Pr}>\mathrm{ItI}$ & Coeff Est & $\mathrm{t}-\mathrm{Val}$ & $\mathrm{Pr}>\mathrm{ItI}$ \\
\hline Intercept & 0.398 & $5.57^{* *}$ & $<.0001$ & 0.416 & $5.75^{* *}$ & $<.0001$ \\
\hline FCash & 0.0101 & $3.25^{* *}$ & 0.0012 & 0.0101 & $3.24 * *$ & 0.0012 \\
\hline Sales & -0.0420 & $-7.21 * *$ & $<.0001$ & -0.0424 & $-7.28 * *$ & $<.0001$ \\
\hline Lev & -0.0118 & $-3.73^{* *}$ & 0.0002 & -0.0116 & $-3.67 * *$ & 0.0002 \\
\hline CB & -0.0090 & -1.20 & 0.2316 & -0.0089 & -1.18 & 0.2372 \\
\hline Size & 0.022 & $3.34^{* *}$ & 0.0009 & 0.021 & $3.30^{* *}$ & 0.0010 \\
\hline ROA & 0.392 & 0.12 & 0.9023 & 0.457 & 0.14 & 0.8863 \\
\hline DivRatio & & & & $5.03 \mathrm{E}-12$ & 1.52 & 0.1283 \\
\hline
\end{tabular}

*Note: DisExp is managers'discretionary expenditures. FCash is free cash flows, and Sales is total sales amount. Lev is the ratio of financial leverage. $\mathrm{CB}$ is a dummy variable in which $\mathrm{CB}=1$ if controlling shareholders hold more than $20 \%$ of the firm's total equity and $\mathrm{CB}=0$ if otherwise. Size is the logarithm of total assets, a corporate size variable. ROA is the ratio of total asset returns, and DivRatio is a dividend payment ratio.

[Table 4] and [Table 5] are the analysis results on the sample period from 2004 to 2010 before the introduction of K-IFRS. In Model 1, Model 2, and Model 3, and Model 4, the dummy variable CB estimates for the controlling shareholders' presence on the manager's discretionary expenditures, DisExp, were $-0.0090,-0.0089,-0.0053$ and -0.0053 , but its t-Vals were $-1.20,-1.18,-0.71$ and -0.053 , respectively. These results show that the $\mathrm{p}$ values are not statistically significant. This means that the dominating shareholders in Korean companies did not have any effect on the discretionary 
expenditures of the managers during the period 2004-2010.

[Table 5] Effects of Controlling Shareholders on Managers'Discretionary Expenditures

- Dependent Variable: DisExp (Managers'Discretionary Expenditures)

- Pre K-IFRS (2004-2010) -

\begin{tabular}{|c|c|c|c|c|c|c|}
\hline \multirow{2}{*}{ Variable } & \multicolumn{5}{|c}{ Model 3 } & \multicolumn{3}{c|}{ Model 4} \\
\cline { 2 - 7 } & Coeff Est & $\mathrm{t}-$ Val & Pr> ItI & Coeff Est & $\mathrm{t}$-Val & Pr ItI \\
\hline \hline Intercept & 0.530 & $7.22^{* *}$ & $<.0001$ & 0.514 & $6.89^{* *}$ & $<.0001$ \\
\hline FCash & 0.0082 & $2.67^{* *}$ & 0.0077 & 0.0083 & $2.68^{* *}$ & 0.0074 \\
\hline Sales & -0.0435 & $-7.55^{* *}$ & $<.0001$ & -0.0434 & $-7.52^{* *}$ & $<.0001$ \\
\hline Lev & -0.0085 & $-2.70^{* *}$ & 0.0070 & -0.0082 & $-2.61^{* *}$ & 0.0092 \\
\hline CB & -0.0053 & -0.71 & 0.4767 & -0.0053 & -0.71 & 0.4748 \\
\hline Size & 0.0202 & $3.09^{* *}$ & 0.0021 & 0.0208 & $3.17^{* *}$ & 0.0015 \\
\hline ROA & -2.622 & -0.82 & 0.4110 & -2.638 & -0.83 & 0.408 \\
\hline DivRatio & $2.73 \mathrm{E}-12$ & 0.83 & 0.4055 & $2.67 \mathrm{E}-12$ & 0.82 & 0.4150 \\
\hline MKBK & 0.0008 & $6.99^{* *}$ & $<.0001$ & 0.00082 & $6.97^{* *}$ & $<.0001$ \\
\hline Beta & & & & -0.008 & -1.15 & 0.2501 \\
\hline
\end{tabular}

*Note: DisExp is managers'discretionary expenditures. FCash is free cash flows, and Sales is total sales amount. Lev is the ratio of financial leverage. $\mathrm{CB}$ is a dummy variable in which $\mathrm{CB}=1$ if controlling shareholders hold more than $20 \%$ of the firm's total equity and $\mathrm{CB}=0$ if otherwise. Size is the logarithm of total assets, a corporate size variable. ROA is the ratio of total asset returns, and DivRatio is a dividend payment ratio. MKBK is the ratio of the common stock market to book value. Beta is a beta coefficient index, a risk measure.

[Table 6] and [Table 7] are the estimated results obtained from the sample from 2011 to 2017, after the introduction of K-IFRS. In Model 1, Model 2 and Model 3, and Model 4, the coefficient estimates of dummy variables $\mathrm{CB}$ for the controlling shareholders' presence were $-0.0250,-0.0222,-0.0191$ and -0.0205 , and its $\mathrm{t}$-Vals were $-3.22,-2.90,-2.54$, and -2.73 , respectively.

[Table 6] Effects of Controlling Shareholders on Managers'Discretionary Expenditures

- Dependent Variable: DisExp (Managers'Discretionary Expenditures)

- Post K-IFRS (2011-2017) -

\begin{tabular}{|c|c|c|c|c|c|c|}
\hline \multirow{2}{*}{ Variable } & \multicolumn{3}{|c|}{ Model 1 } & \multicolumn{2}{c|}{ Model 2 } \\
\cline { 2 - 6 } & Coeff Est & t-Val & Pr> ItI & Coeff Est & t-Val Pr> ItI \\
\hline \hline Intercept & 0.404 & $5.43^{* *}$ & $<.0001$ & 0.705 & $8.68^{* *}$ & $2.46^{*}$ \\
\hline FCash & 0.0078 & $2.42^{*}$ & 0.0157 & 0.0078 & 0.0141 \\
\hline Sales & -0.0781 & $-20.07^{* *}$ & $<.0001$ & -0.0820 & $-21.25^{* *}$ & $<.0001$ \\
\hline Lev & -0.0040 & $-3.16^{* *}$ & 0.0016 & -0.0033 & $-2.63^{* *}$ & 0.0086 \\
\hline
\end{tabular}




\begin{tabular}{|c|c|c|c|c|c|c|}
\hline CB & -0.0250 & $-3.22^{* *}$ & 0.0013 & -0.0222 & $-2.90^{* *}$ & 0.0038 \\
\hline Size & 0.0609 & $11.12^{* *}$ & $<.0001$ & 0.0531 & $9.71^{* *}$ & $<.0001$ \\
\hline ROA & 5.720 & $2.05^{*}$ & 0.0409 & 5.081 & 1.84 & 0.0652 \\
\hline DivRatio & & & & $1.35 \mathrm{E}-11$ & $8.75^{* *}$ & $<.0001$ \\
\hline
\end{tabular}

*Note: DisExp is managers'discretionary expenditures. FCash is free cash flows, and Sales is total sales amount. Lev is the ratio of financial leverage. $\mathrm{CB}$ is a dummy variable in which $\mathrm{CB}=1$ if controlling shareholders hold more than $20 \%$ of the firm's total equity and $\mathrm{CB}=0$ if otherwise. Size is the logarithm of total assets, a corporate size variable. ROA is the ratio of total asset returns, and DivRatio is a dividend payment ratio.

[Table 6] and [Table 7] show that there is a very significant negative correlation between the presence of the dominating shareholders and the discretionary expenditures of the managers in Korean companies from 2011 to 2017, the period after the introduction of K-IFRS. This is a strong evidence consistent with the incentive effect hypothesis. The dominating shareholders of Korean companies can be said to suppress the discretionary expenditures of managers, since they strives to carry out enterprise management emphasizing their company long-term growth and their family reputation rather than exploiting the property of minority shareholders. In [Table 6] and [Table 7], the estimation results considering various control variables, there was no change in the statistical significance of the negative correlation between the controlling shareholders and discretionary expenditures of the managers.

[Table 7] Effects of Controlling Shareholders on Managers'Discretionary Expenditures

- Dependent Variable: DisExp (Managers'Discretionary Expenditures)

- Post K-IFRS (2011-2017) -

\begin{tabular}{|c|c|c|c|c|c|c|}
\hline \multirow{2}{*}{ Variable } & \multicolumn{5}{|c|}{ Model 3 } & \multicolumn{3}{c|}{ Model 4} \\
\cline { 2 - 7 } & Coeff Est & t-Val & Pr> ItI & Coeff Est & t-Val ItI \\
\hline \hline Intercept & 0.772 & $9.61^{* *}$ & $<.0001$ & 0.740 & $9.19^{* *}$ & $<.0001$ \\
\hline FCash & 0.0058 & 1.87 & 0.0611 & 0.0059 & 1.92 & 0.0554 \\
\hline Sales & -0.0813 & $-21.42^{* *}$ & $<.0001$ & -0.0805 & $-21.23^{* *}$ & $<.0001$ \\
\hline Lev & -0.0028 & $-2.28^{*}$ & 0.0230 & -0.0025 & $-2.03^{*}$ & 0.0423 \\
\hline CB & -0.0191 & $-2.54^{*}$ & 0.0111 & -0.0205 & $-2.73^{* *}$ & 0.0063 \\
\hline Size & 0.0518 & $9.62^{* *}$ & $<.0001$ & 0.0530 & $9.86^{* *}$ & $<.0001$ \\
\hline ROA & 2.194 & 0.80 & 0.421 & 1.380 & 0.51 & 0.613 \\
\hline DivRatio & $1.03 \mathrm{E}-11$ & $6.41^{* *}$ & $<.0001$ & $1.04 \mathrm{E}-11$ & $6.53^{* *}$ & $<.0001$ \\
\hline MKBK & 0.00039 & $8.71^{* *}$ & $<.0001$ & 0.00039 & $8.73^{* *}$ & $<.0001$ \\
\hline Beta & & & & -0.0351 & $-3.90^{* *}$ & $<.0001$ \\
\hline
\end{tabular}

*Note: DisExp is managers'discretionary expenditures. FCash is free cash flows, and Sales is total sales amount. Lev is the ratio of financial leverage. $\mathrm{CB}$ is a dummy variable in which $\mathrm{CB}=1$ if controlling shareholders hold more than $20 \%$ of the firm's total equity and $\mathrm{CB}=0$ if otherwise. Size is the logarithm of total assets, a corporate size variable. ROA is the ratio of total asset returns, and 
DivRatio is a dividend payment ratio. MKBK is the ratio of the common stock market to book value. Beta is a beta coefficient index, a risk measure.

\section{Conclusions}

This study attempted to empirically analyze the effect of the presence of controlling shareholders on the discretionary expenditure of managers in corporate governance. In the meantime, it has been generally argued that the controlling shareholders of the company can steal the interests of minority shareholders by conducting real management activities that may pursue their own private interests. Controlling shareholders may take charge of the duties of the managers who directly manage the company, or they may nominate the managers to represent themselves, participating as members of the board of directors.

However, as recently seen in some countries such as East Asia or Germany, it has been argued that the controlling shareholders of family companies are suppressing agency costs because they regard the companies as long-term assets of their families and seek long-term value management.

Therefore, this study conducted an in-depth analysis as to whether the entrenchment management of the controlling shareholders or the exploitation of minority shareholders'property existed in Korean companies, or as to whether the controlling shareholders were suppressing the agency costs by pursuing long-term value management. This means that controlling shareholders regard their companies as long-term assets to protect their family reputation.

The results of the analysis showed that despite the analyses of various statistical models, CB, a dummy variable of the controlling shareholder's shareholding, had a statistically significant negative correlation with DisExp, a discretionary expenditure level variable of the manager. The negative correlation suggests that the greater the stake of the controlling shareholder, the less discretionary expenditure of the manager.

This is a strong evidence to support the incentive effect hypothesis that the controlling shareholders control the agency cost of the manager and pursue family reputation and value management of the company. This study gives an insight that the dominant shareholders in Korean companies have more positive incentive effects to pursue long-term value management rather than the tunnel effect of exploiting the property of minority shareholders.

\section{Acknowledgments}

This research was supported by the Daegu University Research Grant, 2020.

\section{References}

[1] A. Berle and G. Means, The Modern Corporation and Private Property, Commerce Clearing House, (1932)

[2] S. Claessens, S. Djankov, L. Lang, The separation of ownership and control in East Asian Corporations, Journal of Financial Economics, (2000), Vol.58, No.1-2, pp.81-112, DOI: 10.1016/S0304-405X(00)00067-2

[3] S. Claessens, S. Djankov, J. Fan, L. Lang, Disentangling the incentive and Entrenchment Effects of Large Shareholders, The Journal of Finance, (2002), Vol.57, No.6, pp.2741-2771, DOI: 10.1111/1540-6261.00511

[4] A. Achleitner, N. Gunther, C. Kaserer, G. Siciliano, Real Earnings Management and Accrual-based Earnings Management in Family Firms, European Accounting Review, (2014), Vol.23, No.3, pp.431-461, DOI: 10.1080/ 09638180.2014 .895620

[5] J. Stein, Efficient Capital Markets, Inefficient Firms: A Model of Myopic Corporate Behavior, The Quarterly Journal of Economics, (1989), Vol.104, No.4, pp.655-669, DOI: 10.2307/2937861 
[6] R. Razzaque, M. Ali, P. Mather, Real earnings management in family firms: Evidence from an emerging economy, Pacific-Basin Finance Journal, (2016), Vol.40, pp.237-250, DOI: 10.1016/j.pacfin.2015.12.005

[7] M. Jensen, W. Meckling, Theory of the firm: Managerial behavior, agency costs and ownership structure, Journal of Financial Economics, (1976), Vol.3, No.4, pp.305-360, DOI: 10.2139/ssrn.94043

[8] M. Lemmon, K. Lins, Ownership Structure, Corporate Governance, and Firm Value: Evidence from the East Asian Financial Crisis, The Journal of Finance, (2003), Vol.58, No.4, pp.1445-1468, DOI: 10.1111/1540-6261.00573

[9] R. Gopalan, S. Jayaraman, Private Control Benefits and Earnings Management: Evidence from Insider Controlled Firms, Journal of Accounting Research, (2012), Vol.50, No.1, pp.117-157, DOI: 10.1111/j.1475-679X.2011.00431.x

[10] W. Ge, J. Kim, Boards, Takeover Protection, and Real Earnings Management, Review of Quantitative Finance and Accounting, (2014), Vol.43, No.4, pp.651-682, DOI: https://ssrn.com/abstract=2277998

[11] Jaisik Gong, Earnings Management and Credit Rating, Asia-pacific Journal of Convergent Research Interchange, (2020), Vol.6, No.9, pp.13-21, http://dx.doi.org/10.47116/apjcri.2020.09.02

[12] N. Attig, R. Chen, S. Ghoul, O. Guedhami, C. Kwok, J. Pittman, Are insiders equal? Evidence from earnings management in closely held East Asian firms, Research in International Business and Finance, (2020), Vol.54, DOI: 10.1016/j.ribaf.2020.101243

[13] Jaisik Gong, The Effect of Earnings Management on Corporate Debt Policy, Asia-pacific Journal of Convergent Research Interchange, (2020), Vol.6, No.7, pp.81-90, http://dx.doi.org/10.47116/apjcri.2020.07.08

[14] B. Osma, Board Independence and Real Earnings Management: The Case of R\&D Expenditure, Corporate Governance: An International Review, (2008), Vol.16, No.2, pp.116-131, DOI: 10.1111/j.1467-8683.2008.00672.x

[15] Kim Namgon, Knowledge Information Firm's Corporate Divestitures, Asia-pacific Journal of Convergent Research Interchange, (2018), Vol.4, No.1, pp.63-70, http://dx.doi.org/10.14257/apjcri.2018.03.07

[16] D. Cohen, R. Mashruwala, T. Zach, The Use of Advertising Activities to Meet Earnings Benchmarks: Evidence from Monthly Data, Review of Accounting Studies, (2010), Vol.15, No.4, pp.808-832, DOI: 10.2139/ssrn.1013060

[17] Jee-Hyun Kim, Nam-Gon Kim, KOSDAQ IPO firms'advertising expenditures and stock returns, Asia-pacific Journal of Convergent Research Interchange, (2018), Vol.4, No.1, pp.1-10, http://dx.doi.org/10.14257/apjcri. 2018. 03.01

[18] M. Facco, L.H.P. Lang, The Ultimate Shareholdership of Western European Corporations, Journal of Financial Economics, (2002), Vol.65, No.3, pp.365-395, DOI: 10.1016/S0304-405X(02)00146-0 